\title{
THE RELEVANCE ASSESSMENT OF THE LAND USE FOR WIND POWER ENGINEERING IN SETTLEMENTS OF LVIV REGION
}

\author{
Vira SAID, Yulia KHAVAR (D), Liliya VYNARCHYK (D) * \\ Department of Cadastre of Territory, Lviv Polytechnic National University, \\ 12 Bandera Str., Lviv, 79013, Ukraine
}

Received 19 March 2019; accepted 22 November 2019

\begin{abstract}
The aim of the work is to study the relevance of new wind power facilities installation for electricity production in the Lviv region. In this paper, all the necessary conditions for the construction of wind power plants are considered. Analysis of the preferred land plot choice for wind energy generation due to favorable wind conditions and limited environmental impact is carried out. The wind turbines with the capacities, which are most appropriate to use in this region, were selected, as well as the environmental impact of the wind power plants is defined.

It is proved that it is advisable to use wind turbines of the type "ECO 100" with a capacity of 3.0 MW. The results of the research can be effectively used by design and production organizations in the management of geodetic monitoring of the wind power plants state.
\end{abstract}

Keywords: wind power, renewable energy sources, wind power plant, wind turbine, wind potential.

\section{Introduction}

Windpower engineering (WE) is a sphere of energetics, which specializes in the production and use of energy from renewable energy sources. Renewable energy sources include periodic or constant energy flows, which are distributed in nature and are limited only by the stability of the Earth as a cosmoplanetary element: solar energy, hydropower, the thermal energy of nature, wind, etc. (Povkhanych, 2017). The WE development is of great importance, given the future fate of mankind, since combustible minerals, which are the basis for the production of energy at the beginning of the 21st century, have limited reserves, which can eventually be exhausted. The best for humanity to survive in the future is sustainable energy development, in which production and use in society would be balanced and not dependent on natural resources, which are only temporarily available. (Onipko, Korobko, \& Mkhaniuk, 2015). Windpower engineering is one of the means of electricity production using wind power. Unlike other power plants, it can be called environmentally friendly, since it almost does not pollute the environment with waste.

The level of energy development is a basic indicator of the economic and technological development of the country. The high energy intensity of the gross domestic product, the growing demand for energy resources against the background of declining stocks of traditional energy sources and the rise in world prices for them increase Ukraine's dependence on oil and natural gas imports to meet the population's and economy needs for energy products, posing a threat to energy security, which is one of the important components of the economic security of Ukraine (State Committee of Ukraine on Land Resources, 2003). This led to a growing interest in renewable energy sources, among which solar and wind energy have the most development (Stoian, 2015).

Analysis of recent studies, which investigate the solution to the problem of alternative energy sources introducing, namely the wind energy sector, are devoted to the work of Ukrainian and foreign scientists (Pototskyi, Shylkova, \& Maslyennikov, 2014; Adamenko, 2016; Mandryk, 2016; Molodan, 2013; Petruk, Kotsiubynska, \& Matsiuk, 2007; Cleary, Duffy, \& O’Connor, 2012; Martinez, Sanz, Pellegrini, Jiménez, \& Blanco, 2009; Ghenai, 2012).

In their works, they pay attention to the basic plans for the creation and development of wind energy and the use of alternative energy sources in Ukraine and the world. At the same time, not all issues are sufficiently studied, it concerns the review of the wind energy sector, prospects and development trends.

*Corresponding author. E-mail: lvynarchyk@gmail.com 
Table 1 . The frequency of wind directions, $\%$

\begin{tabular}{|l|c|c|c|c|c|c|c|c|c|}
\hline $\begin{array}{c}\text { Weather } \\
\text { stations }\end{array}$ & North & North-East & East & West-East & South & South-West & West & $\begin{array}{c}\text { North- } \\
\text { West }\end{array}$ & $\begin{array}{c}\text { Calm } \\
\text { Slavske }\end{array}$ \\
\hline Stryi & 5 & 15 & 1 & 1 & 31 & 17 & 2 & 6 & 42 \\
\hline Turka & 12 & 8 & 15 & 14 & 10 & 16 & 17 & 17 & 9 \\
\hline
\end{tabular}

The distance from the projected area to the village of Zhupany is $1.2 \mathrm{~km}$.

The aims of the work are:

- the use of wind energy in the Skoliv district of Lviv region and the creation of conditions for the construction of wind power plants.

- to perform the analysis on the choice of an ideal area for wind energy generation due to favorable wind conditions and limited impact on the environment.

- to choose wind turbines of such capacities, which are most appropriate for use in this region.

\section{Materials and methods}

The territory of the Carpathian region has a wind potential with an average annual wind speed of $6.5-7.5 \mathrm{~m} / \mathrm{s}$, allowing build industrial wind power plants (WPP) (Ukrainian Wind Energy Association [UWEA], 2017).

An example of the renewable energy sources use is the construction of WPP in the Zhupanivska village Council of the Skoliv district of the Lviv region. In 2017, a project for the construction and maintenance of WPPs outside the settlement was developed (Figure 1). The territory on which the WPPs construction is envisaged is considered ideal for generating wind energy due to favorable wind conditions and limited environmental impact.
The territory on which the installation of the WPP is planned is located in the southern part of the Skolivskyi district, near the border with the Transcarpathian region, which is bounded by the forest quarters of the state enterprise "Slavske forestry" (Klimetsk and Oporetsk forestry), Slavske Subsidiary Forest Enterprise "Galsillys" (Beskydy and Lavochnyansky forestry) and the area of the villages Lavochne, Oporets, Verhnyaschka, Khitar, Tukholka and Zhupany on the lands of the Zhupanivska village Council outside the settlement. The land plot is defined within the reserve lands and is located along the mountain uplift (Figure 1). The projected land plot for wind power engineering is located approximately $130 \mathrm{~km}$ from the regional center of Lviv, $30 \mathrm{~km}$ from the regional center of Skole, approximately $15 \mathrm{~km}$ from the urban-type settlement Slavske. Near the projected WPP there is a landscape reserve of national importance "Berdo" and a protected tract of local significance "Khitar". The landscape reserve "Berdo" originates from northwest to southeast. On the southern and eastern spurs of the mountain uplift the river Stryi and the Opir rise. The highest points of the mountain uplift reach $1196 \mathrm{~m}$ and $1154 \mathrm{~m}$ (Stanesh Mountain).

The territory of Skolivskyi district has two types of landscapes: low-mountain and mid-mountain, in which

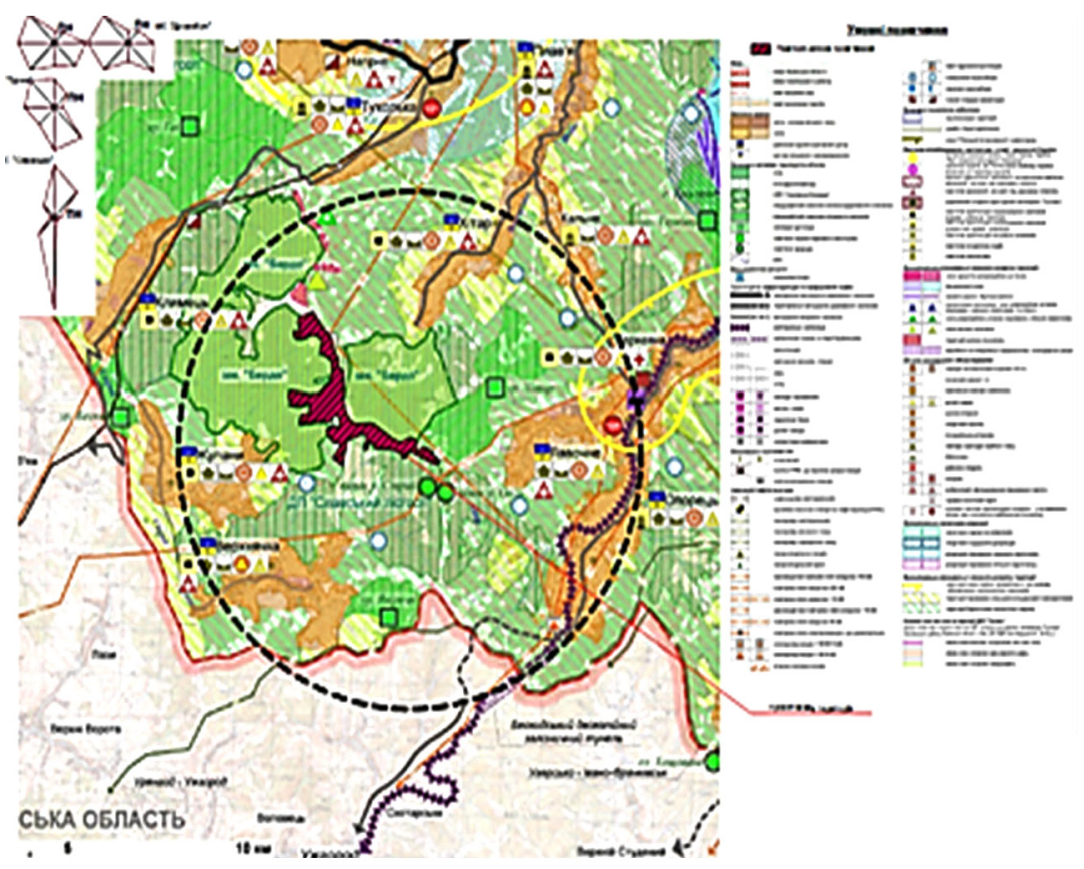

Figure 1. The layout of the WPP location territory in the planning structure of the Skolivskyi district 
there are several types of individual landscapes. Its southern part belongs to the Verkhovyna type of landscape, which is characterized by a small steepness of the slopes and an average forest cover. The terrain is complex, mountainous, the landmarks in different parts of the area vary between 1000.00 and $1200.00 \mathrm{~m}$. Skolivskyi district is characterized by the predominance of southern and northern winds. Table 1 shows the average annual directions and the percentage of winds according to weather stations located in the Slavske village, the cities of Stryi and Turka.

Existing urban planning documentation for the considered territory is the planning scheme of the Skolivskyi district, developed by the State Enterprise State Institute of Urban Design "Mistoproekt" (Figure 1). According to the scheme of the district, this territory is located within the Carpathian Ecological Network (Figure 1).

Conditions are favorable for the construction of WPP because the region has great wind potential. This land management project provides for a lease to Atlas Global Energy Ltd. an agricultural land plot of state property for the placement and maintenance of WPP with the necessary infrastructure (travel roads, an overhead power line, and underground cable power grids, transformer substations). According to the land categories, this land belongs to the land for power plants construction.

\section{Results}

According to the project for the formation of the territory and the establishment of the Zhupanivskyi village Council boundaries, the soils within the boundaries of the land plot are brown mountainous and forest and soddy brown soil shallow, stony and stony medium loamy - (198 d). According to the accepted natural-agricultural zoning of the Lviv region, this site is located within the Turkivskyi (11) natural-agricultural district of the Carpathian province. According to the "List of Highly Valuable Soils" (State Committee of Ukraine on Land Resources, 2003), these soils are not particularly valuable. Considering all the climatic conditions of the land plot, it was decided that the most appropriate to use wind turbines of the type "ECO 100 " with a capacity of $3.0 \mathrm{MW}$. According to the detailed plan of the territory, it is planned to locate a WPP with the necessary infrastructure (distribution point (DP), repair

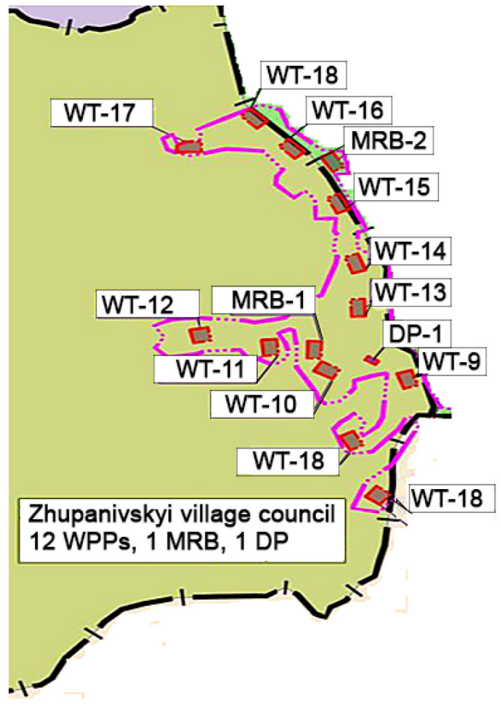

Figure 2. Scheme of territorial subordination of land used for the construction of wind power plants

and maintenance base (RMB) and roads) in the projected area. The wind farm is located on the territory of the Zhupanivskyi village Council outside the Zhupany settlement.

The construction of WPPs is assumed in areas, which are free from the building. The need for reconstruction of buildings is not detected. The total distribution by Zhupanivskyi village Council, on the territory of which the placement of WPPs is projected, with the necessary infrastructure: the wind turbines (WT-7 - WT-18), the distribution point (DP-1), the repair and maintenance base (RMB-1), the access road and the underground cables of the power lines (Figure 2).

The detailed plan provides for the development of an area of 13.2178 hectares (approximately). The number of plots forming the WPP complex is 14 pcs. The plots are allocated for rent for 49 years. The structure of the projected building consists of (Table 2):

- 12 WPPs (wind turbines), the area of the site for one turbine is $1 \mathrm{ha}$. The wind power plant has the form of a cone-shaped tower with a height of up to $100 \mathrm{~m}$, on top of which there is a gondola with a rotor, as well as blades, the length of which varies from $42.5 \mathrm{~m}$ to $44 \mathrm{~m}$ (Figure 3).

- One distribution point with an area of 0.2450 hectares near WT-9 and WT-10.

Table 2. Objects, which are part of a WPP

\begin{tabular}{|l|c|c|c|c|c|c|c|c|c|c|c|c|}
\hline \multicolumn{10}{|c|}{ Technical and economic indicators } \\
\hline $\begin{array}{l}\text { Village } \\
\text { Council }\end{array}$ & \multicolumn{2}{|c|}{ WT } & \multicolumn{2}{|c|}{ DP } & \multicolumn{2}{c|}{ Substation } & \multicolumn{2}{c|}{ RMB } & \multicolumn{2}{c|}{ Total plots } & Roads & $\begin{array}{c}\text { Power lines } \\
\text { (Type 1) }\end{array}$ \\
\cline { 2 - 12 } & Number & $\begin{array}{c}\text { Area, } \\
\text { ha }\end{array}$ & Number & $\begin{array}{c}\text { Area, } \\
\text { ha }\end{array}$ & Number & $\begin{array}{c}\text { Area, } \\
\text { ha }\end{array}$ & Number & $\begin{array}{c}\text { Area, } \\
\text { ha }\end{array}$ & Number & $\begin{array}{c}\text { Area, } \\
\text { ha }\end{array}$ & $\begin{array}{c}\text { Length, } \\
\text { km }\end{array}$ & $\begin{array}{c}\text { Length, } \\
\mathrm{km}\end{array}$ \\
\hline $\begin{array}{l}\text { Zhupa- } \\
\text { nivskyi } \\
\text { village } \\
\text { Council }\end{array}$ & 12 & 12.0 & 1 & 0.2450 & - & - & 1 & 0.9728 & 14 & 13.2178 & 18.63 & - \\
\hline
\end{tabular}


One maintenance and repair base (MRB) (sanitary classification of the enterprise - 5 of sanitary protection zone $50 \mathrm{~m}$ ). The maintenance and repair base includes:

- administrative building with a central control point;

- workshop for the repair of electrical equipment;

- material and technical staff;

- open area for oversized vehicles with a truck crane;

- parking for passenger cars;

- long vehicles parking;

- a platform under a canopy for storage of structures;

- firefighting water storage tanks;

- facilities for the treatment of domestic wastewater ("BIOTAL").

- power transmission line supports;

- service lanes.

The road access to the WPP is designed from the international road M-06 Kyiv-Chop of the 1st category, which runs from the north side of the projected site. From the highway M-06 the arrival No. 2 to the Klimets village through the Zhupany village is provided (Figure 4).

The road accesses are intended to be laid on existing dirt roads of agricultural purpose. For this purpose, it is planned to use modern environmentally friendly construction technologies (the road surface is formed from existing reclaimed soil and cement mortar, the pavement color is green).

The construction of WPPs and infrastructure does not provide the development of quarries on the territory of WPPs and adjacent territories, as well as deforestation. The creation of such a road network will provide fire brigades with access to forest areas. The technological passages for transportation of wind turbine elements and other materials during construction, and after its completion,

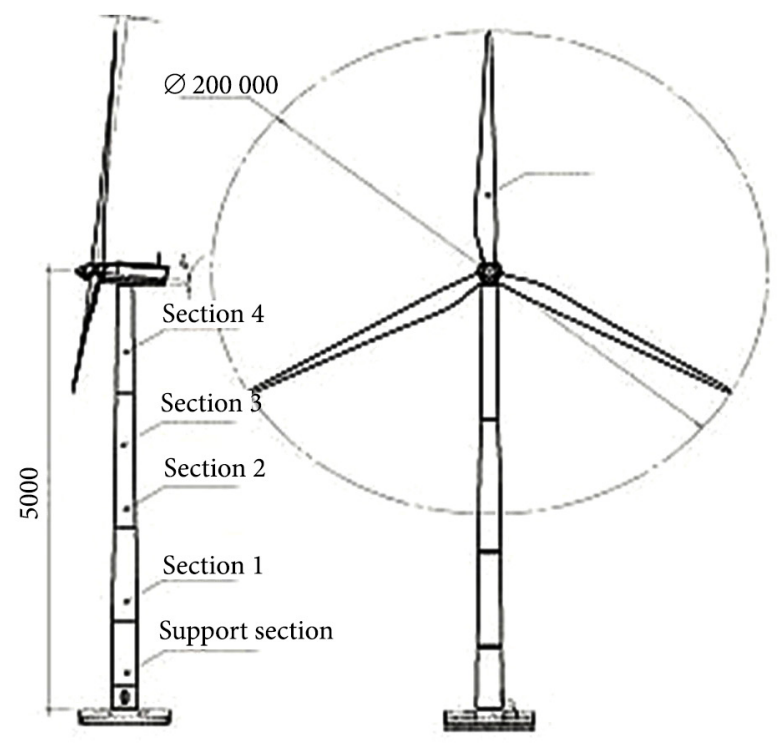

Figure 3. Scheme of a wind turbine

as well as for maintenance of the wind farm are designed. According to the results of geological surveys and engineering and construction assessment of the territory within the boundaries of the territory detailed plan, the physical-geological processes and phenomena unfavorable for construction - are absent.

The land management project provides general and special measures for the preparation of an area favorable for construction. The general measures include:

- maximum preservation of the natural topography, soil cover, and existing green spaces;

- the volume of earthworks is performed considering the use of soil at the construction site, which is displaced;

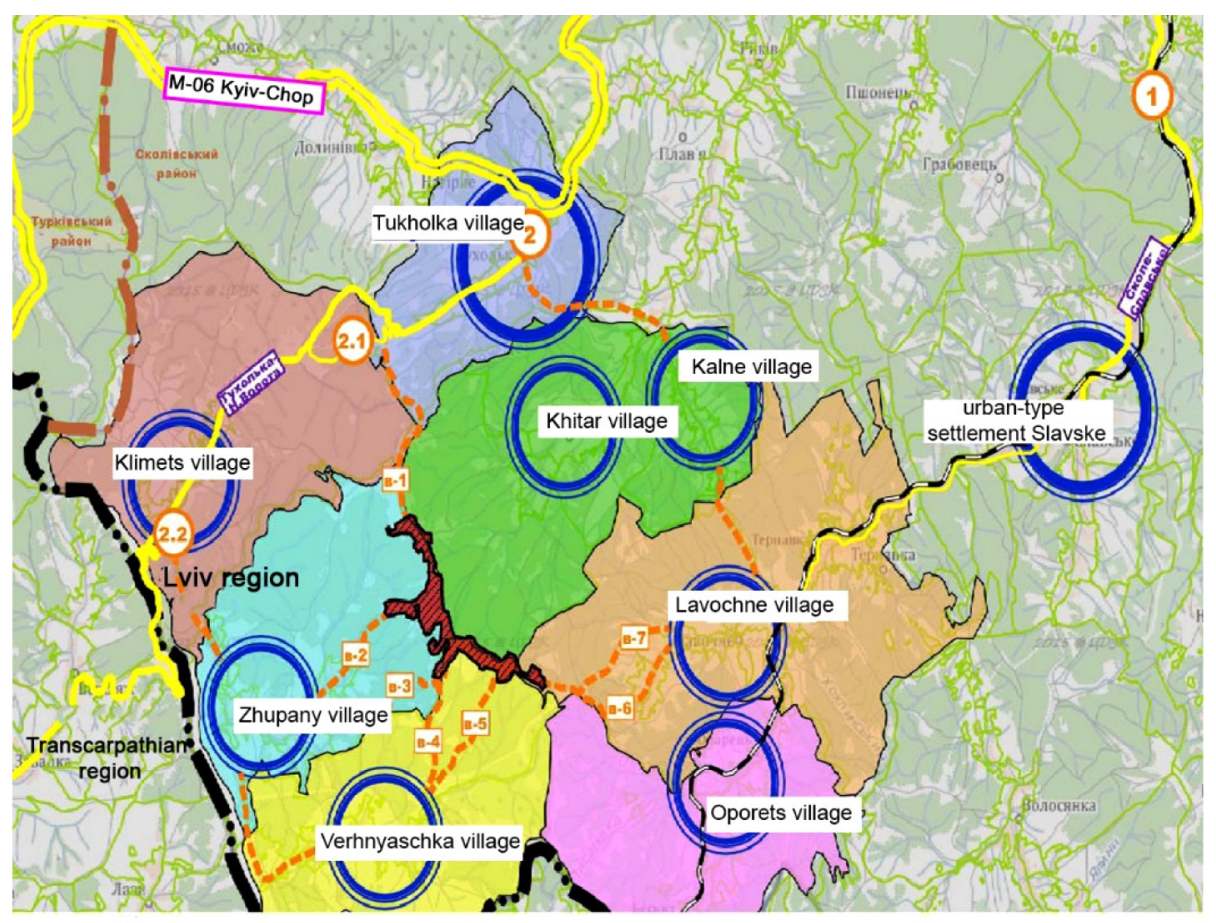

Figure 4. Scheme of road accesses to the WPP territory 
- organization of surface water removal with a slope in the direction of lowering the terrain with speeds, which exclude soil erosion;

- the topsoil layer, which is cut off before the start of earthworks under the entire area and which is designed for access roads, platforms for wind turbines, power cable channels, the territory of the DP and for $\mathrm{RMB}$, is used for land reclamation on the site or behind the site.

The special measures include:

- engineering protection of soil from landslides is assumed;

- slopes need to be strengthened by the drainage layer with the geotextile geogrids;

- the slopes are strengthened by turfing, planting of trees and shrubs with a strong root system;

- install the impervious prisms of compacted clay in the body of the slopes;

- the mound of the territory raising should be performed with layer-by-layer compaction (by 0.20 $0.40 \mathrm{~m}$ ) using trailing rollers and leveling the surface of each layer.

The territory relief allows providing an organized collection and removal of stormwater and sewage spring snowmelt. Drainage of atmospheric and meltwater occurs due to their infiltration into the ground. Due to the relief and the longitudinal profile of the carriageways, drains are discharged to the adjacent territory.

The structure of the engineering preparation of the territory includes:

- the vertical layout of the territory;

- the surface drainage.

The following works are supposed to be performed at the site:

- the fencing of RMB, substation and DP areas;

- the landscaping (seeding perennial grasses).

The territory, which is designed for allocation, should be refined and provided with lighting. Parts of the sites near the WPPs, which during the construction period is concreted, remains solid, the rest of the territory is subjected to the restoration of the grass cover. The technological process of wind energy production does not include the use of fuel, water, and other natural resources. Air emissions during the operation of WPPs are absent. Process wastes - are absent. Construction waste after construction and assembly and household waste during operation will be stored in specially designated containers with their subsequent removal in consultation with the sanitary-epidemiological station of the district. The design and construction of a WPPs in the Skolivsky district is carried out in accordance with the applicable rules of the DBN and ISO (Derzhkombud, 2002; Cleary et al., 2012; Martinez et al., 2009; Ghenai, 2012), including the development of the project "environmental protection" aimed at protecting the environment. The objects of WPP in general and wind turbines are in particular equipped with automatic alarm and fire alarm systems to prevent a fire at the WPP and adjacent areas, including agricultural land and forest fund. The operation of the WPP provides for the provision of security measures, in particular, the installation of video surveillance equipment and the organization of physical security. This will limit the access of third parties to the territory of the WPP and the adjacent territory and will make it possible to prevent illegal deforestation, destruction of fauna, poaching, arson, and the occurrence of fires. In order to protect the environment, the project detailed plan includes measures for the protection of soils, water, and air. Electricity production using wind energy helps to prevent atmospheric air pollution in comparison with electricity production at thermal power plants. In addition, the production of electricity at wind farms save fossil natural resources (coal, gas, fuel oil, uranium ore), which are necessary for the production of electricity at thermal power plants and nuclear power plants. The area is well ventilated and receives sufficient solar radiation. The air environment on the territory has a high capacity for self-cleaning. The project involves the use of energy-saving and environmentally friendly technologies that will reduce emissions of harmful greenhouse gases into the atmosphere (Shydlovskyi, 2007).

During the construction and operation of WPPs, there is no impact on surface water bodies, since no water is used in the process. The influence of water in case of emergency situations is excluded since there are no surface waters in the area where the WPP is located. In the event of an accident (although they are extremely rare), to prevent the ingress of oil into the soil, it is proposed to set up the oil receiving channel in the concrete foundation of the wind turbine, where the oil will be temporarily stored until the emergency crews remove it (Kravchenko, 2009).

Considering possible landslides on the territory of the WPPs, it is proposed to carry out monolithic reinforced concrete foundations for wind turbines on injection piles ("TITAN" micropiles), and for cable trays on a $100 \mathrm{~mm}$ thick concrete base (concrete class B 3.5-M50). All earthworks associated with the construction of WPPs will be carried out considering the instructions of the wind turbine manufacturer, pointing to local specific geophysical conditions by such methods, which would guarantee the safety of wind turbines on the one hand, and lead to the slightest impact on the environment on the other hand.

The aerodynamic noise from the blades of the wind turbine does not exceed the background noise, which creates wind at a speed of $8 \mathrm{~m} / \mathrm{s}$. The level of infrasound, which also has an aerodynamic origin, will not be high since equipment with a minimum level of infrasound will be installed (Kuzmina, 2015). Noise from building machinery during the construction of WPPs will be temporary. The influence of operating WPP on the animal world has been studied in Europe for many years. Experience in operating wind turbines in different countries has shown that various fauna representatives usually adapt to manmade objects (Naraievskyj, 2017). 
During construction, an anxiety and mechanical habitat disturbance of animal world representatives are predicted. Anxiety factors may be concerns noise and vibration. Vibration and interference with living space are considered as a minor threat to flora and fauna. Considering that the construction of a WWPs will be accompanied by recultivation with the restoration of disturbed land, and, consequently, the habitat of animals, it can be said that the influence during construction, in general, will be temporary moderate. For quick adaptation of animals to the new facilities, the installation of wind turbines is recommended to be carried out in turns. Thus, in general, the influence character of construction and operation of WPPs on fauna is moderate.

\section{Discussions}

Comprehensive development of alternative energy is an important task for the Lviv region, the solution of which will allow Ukraine to become fully energy independent and significantly improve the ecological state of the environment. The solution to this problem is closely related to the safety of wind power stations operation and environmental protection. Wind turbines, like all other manmade objects, have problems caused by exposure to birds, noise, land use, and aesthetic impact on the landscape. In general, the influence factors of the renewable energy sources (except for noise and electromagnetic radiation) is defined as insignificant in comparison with traditional sources of electric power generation.

\section{Conclusions}

After analyzing and considering the geographical and climatic characteristics of the Skolivskyi district, we can conclude that this territory can be used for wind power engineering. The land plot where the construction of the WPP is considered is ideal for generating wind energy in the presence of favorable wind conditions and limited environmental impact. Considering the low population density in these territories, we chose to install wind turbines of the type "ECO 100" with a capacity of 3.0 MW in a small settlement in the territory of the Zupanskyi village Council outside the settlement to ensure their energy autonomy. The environmental impact of wind power plants has been determined.

\section{Funding}

The research has no funding.

\section{Author contributions}

Vira Sai conceived the study and was responsible for the design and development of the data analysis. Yulia Khavar and Liliya Vynarchyk were responsible for data collection, analysis and interpretation.

\section{Disclosure statement}

Authors have no competing financial, professional, or personal interests from other parties.

\section{References}

Adamenko, Y. O. (2016). Obgruntuvannia naikrashchykh tekhnolohii vykorystannia vitrovoi enerhii dostupnykh dlia vprovadzhennia u Karpatskomu rehioni. Ekolohichna bezpeka ta zbalansovane resursokorystuvannia, 1, 149-157. Retrieved from http://nbuv.gov.ua/UJRN/ebzp_2016_1_21

Cleary, B., Duffy, A. \& O’Connor, A. (2012, July 10-12). Using life cycle assessment to compare wind energy infrastructure. In International Symposium on Life Cycle Assessment and Construction, Nantes, France (pp. 31-39).

Derzhkombud. (2002). Mistobuduvannia. Planuvannia i zabudova miskykh i silskykh poselen (Derzhavni budivelni normy Ukrainy 360-92**). Kyiv: Derzhkombud.

Ghenai, C. (2012). Life cycle analysis of wind turbine. In Ch. Ghenai (Ed.), Sustainable Development - Energy, Engineering and Technologies - Manufacturing and Environment (pp. 19-32). London, UK: IntechOpen. https://doi.org/10.5772/29184

Kravchenko, D. V. (2009, October 30-31). Suchasnyi stan ta perspektyvy rozvytku vitrovoi enerhetyky v Ukraini. In V International Scientific and Practical Conference "Science in the Information Space". Retrieved from http://www.confcontact. com/2009ip/kravch.php

Kuzmina, M. M. (2015). Development of wind energy in Ukraine. Economic Theory of Law, 2, 133-141. Retrieved from http://nbuv.gov.ua/UJRN/Vnyua_etp_2015_2_13

Mandryk, O. M. (2016). Analiz vykorystannia potentsialu vitrovoi i soniachnoi enerhii v Karpatskomu rehioni. Ekolohichna bezpeka ta zbalansovane resursokorystuvannya, 1, 158-166.

Martinez, E., Sanz, F., Pellegrini, S., Jiménez, E. \& Blanco, J. (2009). Life cycle assessment of a multi-megawatt wind turbine. Renewable Energy, 34(3), 667-673. https://doi.org/10.1016/j.renene.2008.05.020

Molodan, J. E. (2013). Wind turbine life cycle features as a factor affecting landscape components. Fizychna heohrafiya ta heomorfolohiya, 3(71), 167-176. Retrieved from http://nbuv. gov.ua/UJRN/fiz_geo_2013_3_25

Naraievskyj, S. V. (2017). Comparative analysis of the efficiency of wind energy in the leading countries of the world and Ukraine. Efektyvna ekonomika, 5. Retrieved from http://www. economy.nayka.com.ua/?op=1\&z=5587

Onipko, O. F., Korobko, B. P., \& Mkhaniuk, V. M. (2015). Vitroenerhetyka ta enerhetychna stratehiia. Kyiv, Ukraine: Feniks.

Petruk, V. H., Kotsiubynska, S. S., \& Matsiuk, D. V. (2007). Ukraine power potential of alternative energy, Visnik Vinnic'kogo politehnichnogo institutu, 4, 90-93. Retrieved from https://visnyk.vntu.edu.ua/index.php/visnyk/article/ view/481

Pototskyi, D. V., Shylkova, L. V., \& Maslyennikov, A. M. (2014). Prospects of development of the wind power plants of Ukraine. Bulletin of NTU "KhPI", 38(1081), 138-145. Retrieved from http://web.kpi.kharkov.ua/elmash/wp-content/ uploads/sites/108/2017/03/2014_18.pdf

Povkhanych, A. Y. (2017). Wind power as a key element of energy strategy. Scientific herald of Uzhgorod National University, 13(2), 81-86. Retreived from http://www.visnyk-econom. uzhnu.uz.ua/archive/13_2_2017ua/19.pdf 
Shydlovskyi, A. K. (2007). Enerhoefektyvnist ta vidnovliuvalni dzherela enerhii. Kyiv, Ukraine: Ukrainski entsyklopedychni znannia.

State Committee of Ukraine on Land Resources. (2003). Pro zatverdzhennia pereliku osoblyvo tsinnykh hruntiv. Retrieved from https://zakon.rada.gov.ua/laws/show/z0979-03?lang=uk

Stoian, O. Y. (2015). State regulation of wind-power engineering development in Ukraine: features, tendencies, energy potential. Theory and Practice of Public Administration, 1(48), 1-8. Retreived from http://www.kbuapa.kharkov.ua/e-book/ tpdu/2015-1/doc/2/08.pdf

Ukrainian Wind Energy Association. (2017). Vitroenerhetyka Ukrainy 2017. Retrieved from http://www.uwea.com.ua 